on applied biology - to which the Brussels programme is directed - depends on the scale and quality of communications among scientists, and that the principal contribution of the biomolecular engineering programme would have been to set up a network of working contacts throughout Europe. A single European state does not have sufficient biotechnologists to make significant advances in competition with the United States or Japan, they argue.

This point appears to have been lost on the research committee of the Council of Ministers, which has now passed the problem to the diplomatic level in Brussels - the committee of permanent representatives, Coreper. But with the present low level of diplomatic concord in the Community, there seems little hope of a resolution. - Britain's recent white paper on biotechnology was roundly condemned by British researchers at the second European conference on biotechnology at Eastbourne last week. Dr Duncan Davies, whose chief scientist's office at the Department of Industry produced the white paper, made a flying visit to the meeting to defend his position. He was subjected to a barrage of speeches from the floor, but managed to squeeze in that he would review the white paper's provisions on the education and training of biologists. Informed opinion, however, expects little to come of such a review. Robert Walgate

\section{Taking note, or shelving?}

The British House of Commons last week "took note" of the European proposed programme on biomolecular engineering, a mechanism which allowed the Under Secretary of State for Industry, Mr Michael Marshall, to state the government position on the latest version of the programme.

The original proposal (for 26 million European Units of Account (EUA) over five years) was "over-ambitious in both scope and expenditure', said $\mathrm{Mr}$ Marshall; but the shift of emphasis away from research and towards training in the revised proposals (an 11.8 million EUA four-year compromise proposed in Brussels) "is of an extent not hitherto contemplated".

Without naming France, Mr Marshall indicated that the government did not share the French view that there is a significant lack of training opportunities. Nevertheless Britain would continue to work towards an acceptable compromise, he said.

Tam Dalyell MP, described by one member of the House as "almost a walking Select Committee on Science and Technology", warned the minister to be wary of the French position, saying that the new proposals "by pooling training, hand over British expertise to the French for little or no return". The House took note. Robert Walgate

\section{European Space Agency Space on the cheap}

\section{Paris}

The member states of the European Space Agency are still at odds about the future. Although they have agreed to the proposal of $\mathrm{Mr}$ Erik Quistgaard, the agency's director-general, that the budget should be reduced to 60 per cent of its present level over the next ten years, they are hopelessly divided on how to spend the money. The problem is that the reduced budget will not support the three programmes that have been put forward in telecommunications, space transportation systems and science. So the agency is wrestling with priorities.

Quistgaard's suggestion that the mandatory science budget, to which all member states must contribute, should be increased by 60 per cent over the next ten years has so far fallen on stony ground. Britain, Sweden, Spain and Belgium have flatly turned down the proposal; only Germany has agreed to contribute in full.

Lacking unanimous agreement, the agency may therefore have to take the unprecedented step of admitting optional contributions to scientific programmes. That, according to Ernst Trendelenberg, director of scientific programmes, could divide European space scientists into privileged and under-privileged depending on their nationality.

Germany and France are the most likely to favour this approach, but for different reasons. Germany would like to divert some of the money spent on Spacelab to science, and France is keen that there should be a steady stream of satellites for launching with Ariane, whose development it has supported heavily. Britain, on the other hand, says the agency is too inefficient to justify more spending on science.

The most heated debate in the agency, however, is about the choice of space applications for the next ten years. The two chief candidates - space transportation systems and telecommunications - have been proposed by France and Britain. France argues that Europe must have a launcher to rival the space shuttle, especially if materials processing experiments on Spacelab demonstrate that space has commercial potential. It would like to develop more sophisticated versions of Ariane and ultimately an unmanned partly-reusable space transportation system called Solaris, which is expected to be put before the agency's council at the end of the year.

France disagrees with Britain's proposal to spend more on telecommunications on the grounds that that should be left to industry. Both France and Germany withdrew from early plans to build a large satellite for direct broadcasting, preferring instead a bilateral programme. Neither believes that the "Large Satellite Programme"' (L-sat), due to be approved
Quistgaard awaits orders Paris

Erik Quistgaard, director-general of the European Space Agency, is optimistic. The present stalemate between the member states, he says, might be broken if the users of space technology were more intimately involved. Thus post offices, users of remote sensing data and industrial users of experiments on Spacelab rather than government departments should have more influence over what the agency does. The problem is that although most states know what they want from space, few are decided about their expectations of the agency.

Mr Quistgaard believes that it is up to member states to tell him what they want. Some delegates, however, are looking to him for solutions. The rejection of his proposal that the science budget should be increased is hardly encouraging.

Quistgaard believes that Europe can and should compete with the United States and others in telecommunications, remote sensing and space transportation systems. He favours unmanned space transportation systems as an alternative to the space shuttle.

Judy Redfearn

in June by Britain, Italy and some of the smaller countries, goes sufficiently beyond their own plans to justify participation. Britain, on the other hand, with a smaller space budget than either France or Germany, sees L-sat as its opportunity to compete for world markets.

The hope is that these two conflicting views can be reconciled. Professor Hubert Curien, director of the Centre National d'Etudes Spatiales, believes that Britain may be moving towards the view that space transportation systems must be developed within the agency. And John Hawkes, of the British Department of Industry, thinks that his French colleagues may now be more ready to agree that telecommunications development beyond L-sat should be supported on a European scale.

If $\mathrm{Mr}$ Quistgaard is to put his ten-year plan into operation, he needs to know soon which of these options the agency should be studying. To pursue both would entail scrapping the agreement reached on the future budget.

Judy Redfearn

\section{Cystic fibrosis}

\section{Diagnostic hopes}

Techniques now being developed at various centres in Britain and the United States have stimulated optimism about new approaches to the prevention of cystic fibrosis. Workers in the field are particularly excited by the prospect of being able to detect carriers of the genetic defect.

Among genetic deficiency diseases, cystic fibrosis is peculiar in that the nature of the underlying molecular defect is as yet unknown. The belief that only a single gene 